\title{
Greetings and Opening Remarks
}

\author{
JAMES K. AVERY \\ President of the International Association for Dental Research, University of Michigan \\ School of Dentistry, Ann Arbor, Michigan 48104, USA
}

It is a privilege and great honor to represent the International Association for Dental Research at the opening of the Sixth International Conference on Oral Biology. The theme of this international conference is "Pharmacological Aspects of Oral Biology." The subjects of this conference include oral fluids, soft tissues, bone, enamel, dentin, pulp, and biomaterials. We are pleased that our Conference Committee has invited such a distinguished group of scientists to assemble here to discuss these timely subjects.

Let us recognize the tremendous efforts of the Conference Committee who have worked so hard in organizing this conference: Dr. Norton M. Ross of Fairleigh-Dickinson University, chairman of the committee, who developed this program and all of its details; Dr. George S. Beagrie of the University of Toronto, chairman of the Local Arrangements Committee and president of the Ontario Section of the IADR, and also all the faculty of the University of Toronto who have assisted him; Dr. Louis P. Gangarosa of the Medical College of Georgia, special editor for the conference; Dr. Mogens R. Skougaard of the Royal Dental College of Copenhagen, immediate past-president of the IADR; Dr. Dennis C. Smith of the University of Toronto who has done a great job developing the social program, in spite of the mail strike; Dr. Anthony R. Volpe who, together with Dr. William King of the Colgate-Palmolive Company, has been a great assistance from the beginning in the organization of this conference; Dr. Arthur R. Frechette, secretary-treasurer of the IADR, who so capably assists in all matters of the IADR; and Dr. David F. Mitchell, editor of the Journal of Dental Research, who is ulti- mately responsible for the publication of the proceedings of this conference as a special issue of the Journal. I would also like to recognize Dr. Gunnar Ryge, who did all the early work on organizing this conference.

As you know, there have been five past International Conferences on Oral Biology. The first, held in New York City in 1959, was entitled "Enamel, Biochemical and Nutritional Factors in Dental Caries, Oral Soft Tissues and Oral Environment and Bone." The second conference, held in Bonn, Germany in 1962, had as topics "Epidemiologic Research in Dentistry, Forensic Dentistry, Investigations on Oral Neoplasia, Growth and Development Problems, Preventive Dentistry and Oral Microbiology." The third conference, held in London in 1965, was concerned with such subjects as "Connective Tissue, Repair, Neoplasia, Genetics, Fluid Environment of the Teeth and Tooth Form and Structure." The fourth conference, held in Copenhagen, Denmark in 1968, was concerned with the subject of "Interface Biology of the Oral Structures." The fifth conference, held in Zurich, Switzerland in 1971, was titled "Enzymes in Oral Biology." We are now looking forward to this sixth conference with much anticipation, certain that it will be as great a contribution as the ones in the past.

Finally, I wish to thank Mr. Jules Blake, vice-president for research of the ColgatePalmolive Company for making this conference possible and Mr. Dale Sherott, president of the Colgate-Palmolive Company of Canada, who is our host aboard the Thomas Rennie on Lake Ontario.

A hearty welcome to all of you. May the conference proceed. 